\title{
Tree Productivity in the Semiarid Zone of Brazil
}

\author{
P.C.F. LIMA \\ EMBRAPA-CPATSA, Cx.P. 23, 56.300, Petrolina, PE. (Brazil)
}

(Accepted 11 March 1986)

\begin{abstract}
Lima, P.C.F., 1986. Tree productivity in the semiarid zone of Brazil. For. Ecol. Manage., 16: 5-13.

The present study examined the wood and fodder productivity of Leucaena leucocephala (LAM) de Wit, Prosopis juliflora (SW) DC, Eucalyptus camaldulensis Dehnh, Eucalyptus crebra Muell., and Anadenanthera macrocarpa (Benth) Brenan, planted in Petrolina, Pernambuco State, as a semiarid zone in northeastern Brazil. The seedlings were planted in a plowed and harrowed field at a spacing of $3 \times 2 \mathrm{~m}$. Average height and survival rates were measured 1,3 , and $5 \mathrm{y}$ after planting. A wood volume estimate was made 5 y after planting. The wood productivity of Prosopis, $15 \mathrm{~m}^{3}$ $\mathrm{ha}^{-1}$, was superior to Leucaena $\left(11 \mathrm{~m}^{3} \mathrm{ha}^{-1}\right)$. Both species had lower productivity than E. crebra $\left(24 \mathrm{~m}^{3} \mathrm{ha}^{-1}\right)$, but greater than E. camaldulensis $\left(10 \mathrm{~m}^{3} \mathrm{ha}^{-1}\right)$ and A. macrocarpa $\left(3 \mathrm{~m}^{3} \mathrm{ha}^{-1}\right)$. These productivity values are low compared to those of humid region species, but moderate for the semiarid zone, in relation to the wood productivity of 'caatinga' vegetation. The fodder preductivity of Leucaena was 7.5 metric $t$ of dry matter per ha per year. The pod productivity of Prosopis was estimated to be $6 \mathrm{t}$ per ha per year.
\end{abstract}

\section{INTRODUCTION}

The Brazilian semiarid zone covers approximately $1,160,000 \mathrm{~km}^{2}$, which represents $75 \%$ of the northeastern region and $13 \%$ of the country. The natural vegetation is called 'caatinga', a deciduous woodland type that takes on a whitish-colored aspect during the dry season after the fall of the leaves. The trees are twisted and usually have thorns. The wood productivity is low and the exploitation is extensive and irrational. The wood is used commercially as an energy source in gypsum industries, cement factories, potteries and bakeries. On the farm the wood is used for small construction, fences and firewood.

Since the practice of afforestation (even with fodder species) is not common among the farmers, and the factories and industries that use charcoal as fuel do not have their own plantations, the Brazilian Government has initiated reforestation programs for northeastern Brazil. Consequently, several forestry companies are searching for information about the establishment, management and productivity of appropriate trees for the Brazilian semiarid zone. 
The number of species available for economical exploration in this zone is very limited. Only Prosopis juliflora (SW) DC is used in Government programs for reforestation in the semiarid zone, but studies by the Agricultural Research Center for the SemiArid Tropics (CPATSA) have demonstrated the ability of Eucalyptus crebra Muell., Eucalyptus camaldulensis Dehnh and Leucaena leucocephala (LAM) de Wit to grow fast, with a good survival percentage. These studies also showed that Anadenanthera macrocarpa (Benth) Brenan ('angico') grew more than any of the other native species ( Silva et al., 1980; Pires and Ferreira, 1982; Lima et al., 1982b).

This paper reports on the wood and fodder productivity of all these species in the semiarid region of Petrolina, Brazil.

\section{CHARACTERISTICS OF THE REGION}

Petrolina is situated at $09^{\circ} 09^{\prime}$ latitude south and $40^{\circ} 27^{\prime}$ longitude west, at an altitude of $365 \mathrm{~m}$. The landscape is a gently undulating one, broken by a few rocky hills. In general the soils are shallow Latosols with a low water -holding capacity and low organic matter content.

According to the Köppen climatic classification, the climate of the region is of the BSh type with irregular rainfall, concentrated in 2-4 months of the year. Normally, the annual dry season begins in May and extends through December. In Petrolina the average rainfall measured over 22 years is $578.1 \mathrm{~mm}$, and the average temperature is $27^{\circ} \mathrm{C}$. The annual rainfall was $510 \mathrm{~mm}$ in $1979 ; 536$ $\mathrm{mm}$ in 1980; $500 \mathrm{~mm}$ in 1981; $342 \mathrm{~mm}$ in 1982; $540 \mathrm{~mm}$ in 1983 and $654 \mathrm{~mm}$ in 1984.

Forest inventories carried out by Tavares et al. (1970) and Lima et al. (1979) estimated the wood volume, with a diameter at breast height (DBH) greater than $5 \mathrm{~cm}$, to be 7 and $12 \mathrm{~m}^{3} \mathrm{ha}^{-1}$, respectively.

Cattle, sheep and goats are the main livestock in the region. The limiting factor for livestock production is the low quantity and quality of dry season forage. Fifteen to twenty ha of 'caatinga' vegetation are required to feed one head of cattle in this region (Salviano et al., 1982).

\section{ESTABLISHMENT OF SPECIES}

Introduction trials of Eucalyptus in the semiarid zone of northeastern Brazil have been conducted by EMBRAPA (Brazilian Agricultural Research Corporation) to define the best species and provenance. In Petrolina, 13 species and 90 provenances of Eucalyptus were introduced prior to 1984.

The first experiments were set up in 1979 in a randomized complete block design with the same number of replicates for all the treatments. Ten species of Eucalyptus were introduced from different provenances including: E. camaldulensis, 10 provenances; $E$. alba, 7 provenances; $E$. exserta, 4 provenances; $E$. 
TABLE 1

Mean survival rates of Eucalyptus, Leucaena, Prosopis and A. macrocarpa in Petrolina

\begin{tabular}{llccl}
\hline \multirow{2}{*}{ Species } & Provenances & \multicolumn{2}{l}{ Survival $(\%)$} \\
\cline { 3 - 4 } & & 1 year & 3 years & 5 years \\
\hline E. camaldulensis & Australia $(10923)^{\text {a }}$ & 100 & 100 & 86 \\
E. crebra & Australia $(6946)^{\text {a }}$ & 98 & 96 & 94 \\
L. leucocephala & Local & 100 & 100 & 90 \\
P. juliflora & Local & 100 & 100 & 98 \\
A. macrocarpa & Local & 93 & 93 & 93 \\
\hline
\end{tabular}

${ }^{a}$ Australian code.

crebra, 2 provenances; $E$. nesophylla, 4 provenances; $E$. polycarpa, 3 provenances; $E$. tesselaris, 2 provenances; $E$. urophylla, 1 provenance; $E$. grandis, 1 provenance; and $E$. citriodora, 1 provenance. The results, five years after planting, showed that E. crebra and E. camaldulensis were the best. The provenances 10533,10510 and 10923 of E. camaldulensis were the best among the 10 tested provenances, with a survival rate higher than $85 \%$. For $E$. crebra both provenances tested (11958 and 6946) had good growth with a survival rate higher than $92 \%$.

Meanwhile, CPATSA is measuring the productivity of 12 native species in Petrolina. The first results three years after planting, show that Anadenanthera macrocarpa, Tabebuia impetiginosa and Caesalpinia ferrea have the greatest growth. This study uses a randomized complete block design with 3 replicates with 16 plants per plot, spaced $3 \times 2 \mathrm{~m}$. Characteristics of soil, site, seed origin, seedling production and methods of planting for all 12 species are described by Lima et al. (1982b).

A study of Leucaena leucocephala and Prosopis juliflora to examine survival, wood and fodder production in Petrolina was initiated in 1979. The experimental design was a randomized complete block with 5 replicates with 25 plants per plot, spaced $3 \times 2 \mathrm{~m}$. The first results showed these species to be suitable for the semiarid region (Lima, 1982). In northeastern Brazil, plantations of Leucaena are rarely used for firewood, but people use it for cattle feed.

The survival percentages for the best species (E. camaldulensis, E. crebra, $L$. leucocephala and $P$. juliflora) from the results obtained in the different experiments established in Petrolina, five years after planting, are given in Table 1 . The data clearly show a good adaptation of the exotic species compared to $A$. macrocarpa, a native species of caatinga.

A locust (Stiphra robusta Mello-Leitão) was observed attacking the trees in the summer. The fodder species, especially Leucaena (Moraes et al., 1980), were attacked by this locust, reducing the fodder available to cattle. A. macrocarpa and P. juliflora were less susceptible to the locust than Leucaena. 
TABLE 2

Mean growth and DBH of Eucalyptus, Leucaena, Prosopis and A. macrocarpa in Petrolina

\begin{tabular}{lllll}
\hline Species & \multicolumn{2}{l}{ Height $(\mathrm{m})$} & $\begin{array}{l}\text { DBH }(\mathrm{cm}) \\
5 \text { years }\end{array}$ \\
\cline { 2 - 4 } & 1 year & 3 years & 5 years & \\
\hline E. camaldulensis & 2.8 & 4.5 & 5.4 & 4.5 \\
E. crebra & 2.2 & 5.1 & 6.1 & 6.5 \\
L. leucocephala & 3.3 & 4.1 & 4.2 & 3.4 \\
P. juliflora & 2.2 & 3.2 & 3.2 & 2.6 \\
A. macrocarpa & 2.3 & 2.5 & 2.6 & 3.2 \\
\hline
\end{tabular}

Twig girdling insects (Oncideres sp.) were observed on branches of Leucaena and Prosopis. The attack was more intensive on Prosopis than Leucaena. Termites were observed in the stems of $A$. macrocarpa but they caused no apparent damage to the plants.

Table 2 shows the growth of different species 1, 3 and 5 y after planting. In the first year $L$. leucocephala had the greatest height but its growth slowed from the third year. The same was true for Prosopis. This was probably due to the competition among the trees for water and nutrients because of the spacing used $(3 \times 2 \mathrm{~m})$.

Considering the irregular rainfall in Petrolina during the period of study, the growth in height of $E$. crebra and E. camaldulensis was very good. Goor and Barney (1976) estimated the height growth of Eucalyptus at $1 \mathrm{~m}$ or more per year, for areas with less than $500 \mathrm{~mm}$ of rainfall. In Açu-Rio Grande do Norte a region with similar rainfall conditions, Pires and Ferreira (1982) found that E. camaldulensis has reached a height of $8.4 \mathrm{~m}$ with a $48 \%$ survival rate, five years after planting.

Souza and Carvalho (1984) examined the performance of eight provenances of $E$. camaldulensis, three years after planting in Teresina-Piauí, a region with $900 \mathrm{~mm}$ of rainfall per year on average. The most productive provenances, 11420,10920 and 12139 , reached $11.9 \mathrm{~m}, 11.7 \mathrm{~m}$ and $10.8 \mathrm{~m}$ in height, respectively, with a $100 \%$ survival rate. Results obtained by CPATSA during a similar trial of E. camaldulensis established at the same time in São Gonçalo-Paraíba, a region similar to Teresina, showed heights of $11.2 \mathrm{~m}, 10.9 \mathrm{~m}$ and $10.1 \mathrm{~m}$ after three years of growth for the provenances 12139,11420 and 10920 , respectively. The best survival rate (97\%) was observed for the provenance 12139 ( $87 \%$ for the other two). In Petrolina, provenance 12139 grew to $4.2 \mathrm{~m}$, with $31 \%$ survival, three years after planting. The provenances 10920 and 11420 grew to 4.0 $\mathrm{m}$ and $4.3 \mathrm{~m}$ and had a survival rate of 85 and $75 \%$, respectively (Lima and Pires, 1985). 


\section{TABLE 3}

Total wood and volume increment of the most promising species for Petrolina region

\begin{tabular}{|c|c|c|c|}
\hline \multirow[t]{2}{*}{ Species } & \multicolumn{2}{|c|}{ Wood volume $\left(\mathrm{m}^{3} \mathrm{ha}^{-1}\right)$} & \multirow{2}{*}{$\begin{array}{l}\text { Volume increment } \\
\left(\mathrm{m}^{3} \mathrm{ha}^{-1} \mathrm{y}^{-1}\right)\end{array}$} \\
\hline & 3rd year & 5 th year & \\
\hline E. camaldulensis & 7 & 10 & 2.0 \\
\hline E. crebra & 15 & 24 & 5.0 \\
\hline L. leucocephala & 7 & 11 & 2.2 \\
\hline P. juliflora & 8 & 15 & 3.0 \\
\hline A. macrocarpa & - & 3 & 0.6 \\
\hline
\end{tabular}

\section{WOOD PRODUCTION}

Both the tortuosity and bifurcation of the stems were taken into account when estimating the wood volume for the species. Leucaena and Prosopis had an average of two and six stems per plant, respectively. In this study all large shoots beginning below breast height were considered to be stems. The Eucalyptus had only one stem without tortuosity while A. macrocarpa had some bifurcations which were not considered because the branches were tiso short and thin.

Table 3 shows that the volume of Prosopis, Leucaena and E. camaldulensis was practically the same in the third year, and half that of E. crebra. In the fifth year the wood production of Prosopis $\left(15 \mathrm{~m}^{3} \mathrm{ha}^{-1}\right)$ was greater than Leucaena $\left(11 \mathrm{~m}^{3} \mathrm{ha}^{-1}\right)$. Both these species had lower production than $E$. crebra $\left(24 \mathrm{~m}^{3} \mathrm{ha}^{-1}\right)$, but greater than E. camaldulensis $\left(10 \mathrm{~m}^{3} \mathrm{ha}^{-1}\right)$ and A. macrocarpa $\left(3 \mathrm{~m}^{3} \mathrm{ha}^{-1}\right)$.

For Prosopis, the volume production in Petrolina $\left(3 \mathrm{~m}^{3} \mathrm{ha}^{-1} \mathrm{y}^{-1}\right)$ was compatible with Webb's estimates (1980) of 3 to $5 \mathrm{~m}^{3} \mathrm{ha}^{-1} \mathrm{y}^{-1}$ in a region with an annual rainfall of 400-500 mm. For E. crebra, the volume production was below the estimates of $10 \mathrm{~m}^{3} \mathrm{ha}^{-1} \mathrm{y}^{-1}$ made by Goor and Barney (1976).

The wood productivity in Petrolina for Eucalyptus, Prosopis and Leucaena could be further increased through studies on plant spacing, fertilization, soil management and the use of water catchment basins.

The average wood volume increment for Leucaena was $2.2 \mathrm{~m}^{3} \mathrm{ha}^{-1} \mathrm{y}^{-1}$, with a $3 \times 2 \mathrm{~m}$ spacing. More recent research done by CPATSA has demonstrated that a $1.5 \times 1.0 \mathrm{~m}$ spacing gives nearly twice the volume production of the $3 \times 2$ $\mathrm{m}$ spacing (Table 4). There was a statistical difference in diameter for the treatments tested, but not in plant height. In the closer spacings the stems were very thin, without branching. 
TABLE 4

Mean survival, height, DBH and volume for different spacings of Leucaena in Petrolina

\begin{tabular}{lllll}
\hline $\begin{array}{l}\text { Spacing } \\
(\mathrm{m} \times \mathrm{m})\end{array}$ & $\begin{array}{l}\text { Survival } \\
(\%)\end{array}$ & $\begin{array}{l}\text { Height } \\
(\mathrm{m})\end{array}$ & $\begin{array}{l}\mathrm{DBH} \\
(\mathrm{cm})\end{array}$ & $\begin{array}{l}\text { Volume } \\
\mathrm{m}^{3} \mathrm{ha}^{-1}\end{array}$ \\
\hline $1.0 \times 1.0$ & 66 & 4.0 & 2.6 & 11.4 \\
$1.5 \times 1.0$ & 84 & 4.3 & 3.0 & 13.6 \\
$2.0 \times 1.5$ & 91 & 4.5 & 3.4 & 11.2 \\
$3.0 \times 1.5$ & 95 & 4.3 & 3.2 & 6.8 \\
$3.0 \times 2.0$ & 86 & 4.6 & 3.6 & 6.2 \\
$3.0 \times 2.5$ & 96 & 4.2 & 3.6 & 5.2 \\
\hline
\end{tabular}

\section{FODDER PRODUCTION}

Economically significant pod production of $P$. juliflora in northeastern Brazil begins in the fifth year after planting. After the 20th year the pod production begins to decrease, so the trees should be harvested for furniture and flooring (Nobre, 1982).

The pod production in Petrolina, according to experimental results from 10 plants randomly sampled from a population of 35 trees, spaced approximately $15 \times 15 \mathrm{~m}$ and with $100 \mathrm{~m}^{2}$ of canopy area per tree, is estimated to be $6 \mathrm{t} \mathrm{ha} \mathrm{h}^{-1}$ $\mathrm{y}^{-1}$. The experimental site was in an experimental irrigation station that probably had a high water table. The total pod number of $P$. juliflora, was estimated on the basis of the average monthly pod production of trees of the same age from May 1983 to March 1985 (Table 5). In the first year of observation the major flowering period began in May and in the second year in June. The greatest flowering occurred in months that had no rainfall.

Even though this plantation was 15 years old there was great variation in pod production, which ranged from 5 to $117 \mathrm{~kg}$ per plant. This variation could well be due to genetic or physiological disturbances; a similar variation occurred in the second year of measurements.

CPATSA is currently selecting trees of $P$. juliflora with superior pod production that will be vegetatively propagated by rooted cuttings. With this selection

TABLE 5

Average pod production from 10 trees of $P$. juliflora in Petrolina

\begin{tabular}{|c|c|c|c|c|c|c|c|c|c|c|c|c|}
\hline \multirow[t]{2}{*}{ Year } & \multicolumn{12}{|c|}{ Production (kg) } \\
\hline & Jan & Feb & Mar & Apr & May & Jun & Jul & Aug & Sep & Oct & Nov & Dec \\
\hline 1983 & - & - & - & - & - & 4.8 & 23.2 & 9.8 & 4.8 & 3.7 & 4.3 & 0.9 \\
\hline 1984 & 0.3 & 1.3 & 1.5 & 2.5 & 1.6 & 0.6 & 0 & 2.4 & 42.3 & 15.4 & 19.9 & 23.2 \\
\hline 1985 & 12.9 & 0 & 0 & - & - & - & - & - & - & - & - & - \\
\hline
\end{tabular}


and planting method it is hoped to increase pod production in the region by more than $80 \%$.

There is no information on wood and pod production for P. juliflora in association with buffel grass (Cenchrus ciliaris) in the semiarid northeast of Brazil. However, research done by Ribaski (1983) in CPATSA, showed that it is necessary to eliminate the grass within a $1 \mathrm{~m}$ radius of the trunk of the trees in the establishment phase of this association. The $P$. juliflora survival rate in this trial at nine months was $10 \%$ without weeding, $90 \%$ with a 2 m diameter weeding and $100 \%$ when there was no association with buffel grass.

$P$. juliflora is also planted with Opuntia in this region. The current results from experiments at the CPATSA experimental station show that the growth of the trees is not affected, but the pod production is delayed. Although there was a $15 \%$ increase in the fresh weight of the Opuntia, this is not statistically significant. The Prosopis was planted with a spacing of $10 \times 10 \mathrm{~m}$ and Opuntia in two double rows, spaced at $3.0 \times 0.5 \mathrm{~m}$. The spacing between the double rows of Opuntia is $1.5 \mathrm{~m}$. In isolated plantings, spaced at $10 \times 10 \mathrm{~m}, P$. juliflora pod production began the second year after planting.

The fodder productivity of Leucaena in Petrolina was previously estimated to be $7.5 \mathrm{t} \mathrm{ha}^{-1} \mathrm{y}^{-1}$ of dry matter, with three cuttings a year (Lima et al., 1982a). The plant spacing was $0.5 \times 1.0 \mathrm{~m}$. The dry matter production of Leucaena in the Brazilian savana (1000 mm rainfall) is $13 \mathrm{t} \mathrm{ha}^{-1} \mathrm{y}^{-1}$ for closer spacings ( 1 to $2 \mathrm{~m}$ between rows), and $5.5 \mathrm{t} \mathrm{ha}^{-1} \mathrm{y}^{-1}$ for spacing ( $5 \mathrm{~m}$ between rows) that permits interplanting with other crops (Kluthcouski, 1980). The results of more recent studies by CPATSA, in Petrolina, with a spacing of $3 \times$ $2 \mathrm{~m}$, and different cultivars of Leucaena are shown in Table 6. The greatest production of dry matter is observed for K62, K8, K28 and K72. There are differences among provenances of the same cultivar, probably due to drought tolerance in Petrolina conditions.

\section{CONCLUSIONS}

The results of research with Prosopis, Leucaena, Eucalyptus crebra and E. camaldulensis show the viability of these species for afforestation programs in the semiarid zone of Brazil. The problems created by insects such as Oncideres and termites are minor compared to the problems of establishing the trees on various soil types with irregular rainfall.

Good soil management, fertilization, and plant selection are probably the key practices which could increase production and survival rates, and help alleviate the firewood shortage in this region. For example, it is estimated that the average consumption of firewood by a family of 5 in this region is approximately $6.7 \mathrm{~m}^{3} \mathrm{y}^{-1}$. In this case it would be necessary for each family to afforest 4-5 ha, so that 1 ha could be cut every year, beginning in the third year, to meet their needs for firewood for cooking. Indeed, an equal area of 'caatinga' vege- 
TABLE 6

Total edible dry matter and total woody material of different varieties of Leucaena in Petrolina

\begin{tabular}{|c|c|c|c|c|c|c|}
\hline \multirow[t]{2}{*}{ Cultivar } & \multirow[t]{2}{*}{ Provenances $^{\mathrm{a}}$} & \multicolumn{2}{|c|}{$\begin{array}{l}\text { Uniformity cut ( } 1 \text { year } \\
\text { after planting) }\end{array}$} & \multicolumn{3}{|c|}{4 and 8 months after uniformity cut } \\
\hline & & $\begin{array}{l}\text { Edible dry } \\
\text { matter } \\
\left(\mathrm{kg} \mathrm{ha}^{-1}\right)\end{array}$ & $\begin{array}{l}\text { Woody } \\
\text { material } \\
\left(\mathrm{kg} \mathrm{ha}^{-1}\right)\end{array}$ & $\begin{array}{l}\text { Edible dry } \\
\text { matter } \\
\left(\mathrm{kg} \mathrm{ha}^{-1}\right)\end{array}$ & $\begin{array}{l}\text { Woody } \\
\text { material } \\
\left(\mathrm{kg} \mathrm{ha}^{-1}\right)\end{array}$ & $\begin{array}{l}\text { Total } \\
\left(\mathrm{kg}^{-1}\right) \\
\left.\mathrm{ha}^{-1}\right)\end{array}$ \\
\hline Unknown & Petrolina-PE & 2.3 & 1.2 & 2.1 & 1.2 & 3.3 \\
\hline K 4 & Sete Lagoas-MG & 3.3 & 1.4 & 4.5 & 2.3 & 6.8 \\
\hline 6 & Linhares-ES & 3.0 & 1.6 & 3.3 & 2.1 & 5.4 \\
\hline 8 & Linhares-ES & 3.5 & 2.1 & 5.5 & 4.0 & 9.5 \\
\hline 8 & Sete Lagoas-MG & 3.1 & 2.1 & 3.8 & 2.1 & 5.9 \\
\hline K 28 & Sete Lagoas-MG & 3.6 & 2.4 & 5.0 & 2.9 & 7.9 \\
\hline K 29 & Sete Lagoas-MG & 2.7 & 2.0 & 2.6 & 1.9 & 4.5 \\
\hline K 58 & Sete Lagoas-MG & 2.7 & 2.2 & 2.5 & 1.6 & 4.1 \\
\hline K 62 & Linhares-ES & 4.4 & 2.4 & 5.0 & 2.8 & 7.8 \\
\hline K 67 & Linhares-ES & 2.0 & 1.3 & 2.7 & 1.8 & 4.5 \\
\hline K 67 & Sete Lagoas-MG & 3.0 & 1.8 & 4.4 & 2.3 & 6.7 \\
\hline K 72 & Linhares-ES & 2.2 & 1.3 & 2.9 & 1.9 & 4.8 \\
\hline K 72 & T. Freitas-BA & 2.2 & 1.6 & 3.2 & 2.0 & 5.2 \\
\hline K 72 & Sete Lagoas-MG & 4.1 & 2.9 & 4.4 & 2.7 & 7.1 \\
\hline K132 & Sete Lagoas-MG & 2.3 & 1.2 & 3.2 & 1.7 & 4.9 \\
\hline Unknown & Sobral-CE & 2.8 & 1.6 & 4.3 & 2.2 & 6.5 \\
\hline
\end{tabular}

a The Brazilian states are abbreviated as follows: $\mathrm{PE}=$ Pernambuco, $\mathrm{ES}=$ Espirito Santo, $\mathrm{MG}=\mathrm{Minas}$ Gerais, $\mathrm{BA}=$ Bahia, $\mathrm{CE}=$ Ceara .

tation would not produce the same wood volume by natural regeneration. Reforestation with $A$. macrocarpa, a native species, would require eight, five and four times the area of E. crebra, P. juliflora and L. leucocephala, respectively, to satisfy the same wood demand.

The principal use for Leucaena in the semiarid zone of Brazil is forage production. A screening trial for forage production identified $\mathrm{K} 62, \mathrm{~K} 8, \mathrm{~K} 28$ and K72 as promising varieties.

The most promising way to increase P. juliflora pod production is through the use of cuttings from superior trees.

\section{REFERENCES}

Goor, A.Y. and Barney, C.W., 1976. Forest tree planting in arid zone. Ronald, New York, 2nd ed., $504 \mathrm{pp}$.

Kluthcouski, J., 1980. Leucaena: alternativa para a pequena e média agricultura. EMBRAPACNPAF, Circular Técnica No. 6, 12 pp.

Lima, P.C.F., 1982. Comportamento silvicultural de Leucaena leucocephala (LAM) de Wit comparado a Prosopis juliflora (SW) DC e Eucalyptus alba Reinv ex Blume, em Petrolina-PE. Universidade Federal do Paraná, Ms.Thesis, Curitiba, Brazil, 98 pp. 
Lima, P.C.F. and Pires, I.E., 1985. Ensaio de Procedências de Eucalyptus camaldulensis Dehnh em Petrolina-PE. EMBRAPA-CPATSA, pesquisa em Andamento No 33, 3 pp.

Lima, P.C.F., Drumond, M.A., Souza, S.M. and Lima, J.L.S., 1979. Inventário florestal da Fazenda Canãa. In: Proceedings of 30 Congresso Florestal Brasileiro, 4-7 December 1978, Manaus, Brazil. Silvicultura, 2, No 14: 398-399.

Lima, P.C.F., Drumond, M.A. and Albuquerque, S.G. de ., 1982a. Frequência de corte em Leucaena leucocephala (LAM) de Wit visando produção de forragem, na região de Petrolina-PE. (Dados preliminares). Petrolina, EMBRAPA-CPATSA. (Unpubl.). 6 pp.

Lima, P.C.F., Souza, S.M. de, and Drumond, M.A., 1982b. Competição de espécies florestais nativas em Petrolina-PE. In: Proceedings of Congresso Nacional sobre Essências Nativas, 12-18 September 1982, Campos do Jordão, Brasil, Instituto Florestal. Silvicultura em São Paulo, 16A (2): 1139-1148.

Moraes, G.J. de, Lima, P.C.F., Souza, S.M. de and Silva, C.M.M. de S. 1980. Surto de Stiphra bitaeniata Leitão (Orthoptera: Proscopiidae) no trópico semi-árido. Ecossistema, 5: 94-99.

Nobre, F.V., 1982. A algarobeira no Nordeste Brasileiro, especialmente no R.G. do Norte. In: Proceedings of I Simpósio Brasileiro sobre Algaroba. 5-7 October 1982, Natal, Brasil. EMPARN. Documentos No 7. pp. 257-282.

Pires, I.E. and Ferreira, C.A., 1982. Potencialidade do Nordeste do Brasil para reflorestamento. EMBRAPA-URFCS, Circular Técnica No 6, 30 pp.

Ribaski, J., 1983. Influência de tratos culturais na sobrevivência e no desenvolvimento de Prosopis juliflora (SW) DC associada a capim buffel. Petrolina-PE. EMBRAPA-CPATSA. (Unpubl.), $3 \mathrm{pp}$.

Salviano, L.M.C., Oliveira, M.C. de, Soares, J.G.G., Albuquerque, S.g. de and Guimarães Filho, C., 1982. Diferentes taxas de lotação em áreas de caatinga I. Desempenho animal. In: Proceedings of XIX Reunião Anual da Sociedade Brasileira de Zootecnia, 15-21 July 1982, Piracicaba, Brasil, pp. 365-366.

Silva, H.D., Pires, J.E., Ribaski, J., Drumond, M.A., Lima, P.C.F., Souza, S.M. de and Ferreira, C.A., 1980. Comportamento de essências florestais nas regiões árida e semiárida do nordeste (Resultados preliminares). Brasília, EMBRAPA-DID, 25 pp.

Souza, S.M. de and Carvalho, J.H. de. 1984. Comportamento de Eucalyptus camaldulensis Dehnh aos 36 meses de idade em Teresina-PI. EMBRAPA-CPATSA, Pesquisa em Andamento No 26, 3 pp.

Tavares, S., Paiva, F.A.F., Tavares, E.J. de, Carvalho, G.H. de and Lima, J.L.S. de. 1970. Inventário florestal de Pernambuco - Estado preliminar das matas remanescentes dos municípíos de Ouricuri, Bodocó, Santa Maria da Boa Vista e Petrolina. Boletim de recursos Naturais. Recife, PE, 8: 149-193.

Webb, D.B., 1980. Guia y clave para selecionar especies en ensayos forestales de regiones tropicales y subtropicales. London, Overseas Development Administration, 275 pp. 